\title{
Anarchist Democracy and the Ideal of Communal Individuality
}

\section{Laurence Davis $^{1}$}

This article examines debates about the relationship between anarchism and democracy, focusing on hidden assumptions regarding the proper relationship between the individual and the community in anarchist theory and practice. My argument is that whereas positions on the issue tend to polarise into competing camps - either anarchism and democracy are fundamentally incompatible, or they are seamlessly compatible - a more nuanced account guided by the anarchist value of communal individuality would allow for the possibility that anarchism is the most radical form of democracy, yet also something qualitatively different from and beyond it. Anarchist democracy, in turn, might be conceived as what I have elsewhere termed a 'grounded utopian' ideal that can renew the democratic promise by recalling its radical heritage, and pushing it towards a horizon both revolutionary and realisable. [Article copies available for a fee from The Transformative Studies Institute. E-mail address: journal@transformativestudies.org Website: http://www.transformativestudies.org (O2020 by The Transformative Studies Institute. All rights reserved.]

KEYWORDS: Anarchism, Democracy, Community, Individuality, Grounded Utopia.

Like such terms as 'freedom', 'equality', 'individuality' and 'community', the concept of democracy is an inherently debatable and changeable idea (Arblaster 1987, 5). In other words, there is no single agreed meaning of the term valid for all peoples at all times. Rather, its meanings at any given moment in history reflect struggles among different groups who understand and practice democracy very differently (Cairns and Sears 2012, 161). It follows that attempts to formulate a comprehensive, fixed and static definition of the term are not only doomed to fail, but are also anti-democratic, insofar as they strive to control and contain something that by its very nature must reflect the

\footnotetext{
${ }^{1}$ Laurence Davis, Ph.D., is College Lecturer and Director of the Ph.D. in Government and Politics at University College Cork, Ireland, and a Series Editor of the Manchester University Press Contemporary Anarchist Studies book series. He is also currently a Senior Member and Academic Visitor at St. Antony's College, Oxford University.
} 